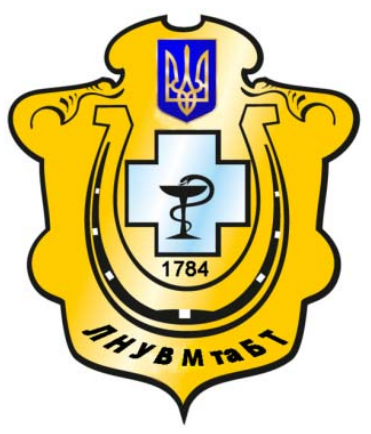

Науковий вісник Львівського національного університету ветеринарної медицини та біотехнологій імені С.3. Гжицького

Scientific Messenger of Lviv National University of Veterinary Medicine and Biotechnologies named after S.Z. Gzhytskyj

doi:10.15421/nvlvet6917

ISSN 2413-5550 print

ISSN 2518-1327 online

$\underline{\text { http://nvlvet.com.ua/ }}$

УДК 371.20:351.851

\title{
Проблеми та перспективи сучасного менеджменту в інформаційному суспільстві
}

\author{
Р.Б. Кухар, О.І. Єлейко, Н.Р. Мотько, О.І. Степанюк, І.О. Рамський \\ soi2014@ukr.net

\begin{abstract}
Львівський національний університет ветеринарної медицини та біотехнологій імені С.3. Гжицького,
\end{abstract} \\ вул. Пекарська, 50, м. Львів, 79010, Україна
}

Досліджується роль інформаційного фактору в системі сучасного менеджменту, відзначається його актуалізаиія в інформаційному суспільстві. Проаналізовано основні принципи та підходи до визначення інформаційного суспільства, характерними рисами якого є зростання ролі інформації $і$ знань у житті суспільства, зростання частки інформаційних комунікацій, продуктів та послуг у ВВП, створення глобального інформачійного простору. 3 поняттям «інформачійне суспільство» тісно пов'язане поняття «інформаційна економіка» особливий тип економіки, характерними особливостями якого є те, щзо визначальним ресурсом виступає інформація. Наведено методи управління в інформаційному суспільстві, зокрема, новий метод управління інформаційне управління. Виділяється иілий клас інформаційних технологій управління підприємством, таких як ERP, CRM, SCM, CSRP, ERP II тощзо.

Управління, як наука, за свою майже столітню історію інтенсивно розвивається, щчо відображсається у відповідних підходах та наукових школах. Еволюиія інформаційних технологій відкрила новий етап розвитку системи менеджменту завдяки появі глобального інформачійного простору. Становлення та розвиток інформачійного суспільства, його послідовний перехід до суспільства знань, зростання ролі та місия інформаційно-комунікаційних технологій в ичих процесах, поспряли тому, щз саме розроблення концептуальних засад ефективного проактивного механізму підготовки й прийняття управлінських рішень, наукових теоретичних та методичних положень зі створення та впровадження в практику такого механізму, формалізація його до рівня конкретних економіко-математичних моделей та інформаційних технологій повинні стати важливими об'єктами дослідження вітчизняної науки.

Ключові слова: інформачія, інформаційне суспільство, менеджмент, інформаційні технології.

\section{Проблемы и перспективы современного менеджмента в информационном обществе}

\author{
Р.Б. Кухар, О.И. Елейко, Н.Р. Мотько, О.И. Степанюк, И.А. Рамский \\ soi_2014@ukr.net
}

Львовский национальный университет ветеринарной медицины и биотехнологий имени С.3. Гжицкого, ул. Пекарская, 50, г. Львов, 79010, Украина

Исследуется роль информаџионного фактора в системе современного менеджмента, отмечается его актуализация 6 информационном обществе. Проанализированы основные принципы и подходы к определению информационного общества, характерными чертами которого является возрастание роли информации и знаний в жизни общества, рост доли информачионных коммуникаций, продуктов и услуг в ВВП, создание глобального информационного пространства. $C$ понятием «информационное общество» тесно связано понятие «информационная экономика» особый тип экономики, характерными особенностями которого является то, что определяющим ресурсом выступает информация. Приведены методы управления в информачионном обществе, в частности, новый метод управления информационное управления. Выделяется иелый класс информационных технологий управления предприятием, таких как ERP, CRM, SCM, CSRP, ERP II и дp.

\section{Citation:}

Kukhar, R.B., Yeleiko, O.I., Motko, N.P., Stepaniuk, O.I., Ramskyy, I.O. (2016). Challenges and opportunities of modern management in the information oriented socie. Scientific Messenger LNUVMBT named after S.Z. Gzhytskyj, 18, 2(69), 87-91. 
Управление, как наука, за свою почти столетнюю историю интенсивно развивается, что отражается в соответствующих подходах и научных школах. Эволючия информационных технологий открыла новый этап развития системы менеджмента благодаря появлению глобального информационного пространства. Становление и развитие информационного общества, его последовательный переход к обществу знаний, рост роли и места информационно-коммуникационньх технологий в этих процессах, поспряль том, что Саме разработки концептуальных основ эффективного проактивного механизма подготовки и принятия управленческих решений, научных теоретических и методических положений по созданию и внедрение в практику такого механизма, формализация его до уровня конкретных экономико-математических моделей и информационных технологий должны стать важными объектами исследования отечественной науки.

Ключевые слова: информация, информационное общество, менеджмент, информационнье технологии.

\title{
Challenges and opportunities of modern management in the information oriented society
}

\author{
R.B. Kukhar, O.I. Yeleiko, N.P. Motko, O.I. Stepaniuk, I.O. Ramskyy \\ soi_2014@ukr.net \\ Lviv National University of Veterinary Medicine and Biotechnologies named after S.Z. Gzhytskyi, \\ Pekarska Str., 50, Lviv, 79010, Ukraine
}

\begin{abstract}
The role of information factor in the system of modern management is researched and its actualization in the information oriented society is reinforced. The article analyses the main principles and approaches to definition of the information oriented society characterized by increase of the role of information and knowledge in the life of the people, growth of the share of information communications, products and services in the Gross Domestic Product, generation of the global information space. The term «nformation oriented society» is closely connected with the term «information economy», a special type of economy distinguished by having information as its determinative resource. The methods of management in the information oriented society are provided herein, in particular, the «information management» as a new management method. The entire class of information technologies of company management, such as ERP, CRM, SCM, CSRP, ERP II and so on, is described in the article.

Management as a science, with its nearly a century of intensive development, which is reflected in the relevant scientific approaches and schools. The evolution of information technology has opened a new stage of development management system by the emergence of a global information space. The formation and development of the information society and its gradual transition to the knowledge society, the growth of the role and place of information and komunikatsiynyh technologies in these processes, pospryaly that came the development of the conceptual foundations of effective proactive mechanism for drafting and decision-making, scientific theoretical and methodological provisions for the creation and implementation in practice of the mechanism, formalizing it to the level of specific economic and mathematical models and information technologies have become important objects of study domestic science.
\end{abstract}

Keywords: information society information management information technology.

\section{Вступ}

В останні десятиліття минулого століття відбувалась кардинальна зміна способів виробництва, світогляду людей, економічних, політичних, соціальних та міждержавних відносин, що призвело до нової промислової революції, що отримала назву інформаційної. Відбувається або вже відбувся перехід до нового виду суспільства, що називають інформаційним. Розуміння особливостей процесів управління, релевантних сучасному етапу розвитку суспільства, потребує ретельного аналізу підходів до визначення інформаційного суспільства. В Україні тривають процеси становлення інформаційного суспільства. Вони охопили всі рівні від держави до ії громадян і перебувають останні кілька років у фокусі особливої уваги керівництва країни. Глибокий аналіз поточного стану національної інформаційної сфери, проведений провідними вітчизняними фахівцями, засвідчив необхідність прийняття системних державних рішень, спрямованих на стимулювання розвитку відповідних процесів, так як згідно з міжнародними індексами стан розвитку інформаційного суспільства в Україні не відповідає поточним світовим темпам. У «Стратегії розвитку інформаційного суспільства в Україні», ухваленій у 2013 році, зазначено, що національна інформаційна сфера перебуває у стані активного становлення, гармонійного включення у глобальний світовий інформаційний простір та $є$ основою розвитку інформаційного суспільства в Україні. Основними стратегічними цілями розвитку інформаційного суспільства та суспільства знань визначено прискорення розробки та впровадження новітніх конкурентоспроможних інформаційно-комунікаційних технологій (IКТ) в усі сфери суспільного життя у державне управління, охорону здоров'я, культуру, освіту, науку, охорону навколишнього природного середовища, бізнес тощо. Розглядаючи інформаційний аспект сучасного менеджменту, зокрема основні типи інформаційних технологій та систем, які використовуються менеджментом, слід вияснити ефективність від їх впровадження в систему управління.

Аналіз останніх досліджень та публікащій. Одним iз перших дослідників, які намагалися обгрунтувати концепцію інформаційного суспільства, був японський професор Й. Масуда, автор праці «Інформаційне суспільство як постіндустріальне суспільство». Основні принципи інформаційного суспільства, викладені ним, переслідування й реалізація цінності часу, вивчення меж можливого, свобода рішень, синергетичні зв'язки, співзвучні передумовам реалізації проактивного підходу до управління. Основою такого управління, що забезпечить розвиток суспільства, має стати виробниц- 
тво когнітивної, систематизованої інформації на основі інформаційних комп'ютерних технологій (Chornous, 2014). Аналіз основних підходів до визначення інформаційного суспільства переконливо демонструє, що його ключовим поняттям $є$ інформація, основою інформаційно-комунікаційні (комп'ютерні) технології, основною метою зміна якості життя. Характерними рисами інформаційного суспільства є зростання ролі інформації і знань у житті суспільства, зростання частки інформаційних комунікацій, продуктів та послуг у ВВП, створення глобального інформаційного простору. Рівень розвитку інформаційного простору суспільства залежить від інформаційних ресурсів, інформаційної та телекомунікаційної інфраструктури, ЗМІ, ринку інформаційних технологій, засобів зв'язку, інформаційних продуктів та послуг, поєднані зі світовими відкритими мережами. В усьому світі сьогодні інформаційний сектор зростає швидше, ніж економіка в цілому. Швидко збільшилася частка працездатного населення, зайнятого в інформаційній галузі. Обробка інформації перетворилась в нову індустрію, в структурі економіки склалась потужна інформаційна область. Бурхливий розвиток інформаційних і телекомунікаційних мереж став потужним каталізатором багатьох інтеграційних процесів. 3 цими процесами пов'язана поява особливих соціальних формацій віртуальних мережних товариств, які стали новою формою мобілізації політичних та економічних ресурсів. Якщо в аграрному суспільстві економічна діяльність була пов'язана з виробництвом продуктів харчування, а обмежуючим фактором виступала земля, індустріальному суспільстві головним було виробництво товарів, а обмежуючим фактором капітал, то в інформаційному суспільстві основною економічною діяльністю $\epsilon$ виробництво та застосування інформації для ефективного функціонування інших форм виробництва, а обмежуючим фактором стає знання. У такому суспільстві центральними факторами $\epsilon$ інформація і знання, які доповнюють, а в багатьох випадках заміщують працю як джерела доданої вартості. 3 поняттям «інформаційне суспільство» тісно пов’язане поняття «інформаційна економіка». В деяких дослідженнях їх навіть розглядають як синоніми. Інформаційна економіка філософсько-економічний термін, що означає особливий тип економіки, органічно притаманний постіндустріальному суспільству, характерними особливостями якого $є$ те, що визначальним ресурсом виступає інформація, а в структурі зайнятих переважають робітники розумової праці (Chornous, 2014).

Інформація стає домінуючим чинником серед факторів виробництва, перестає бути безкоштовним товаром, враховуючи попит на неї. Завдяки інформації відбувається соціально-технологічна трансформація індустріального суспільства. Процеси виробництва, обробки, споживання інформації змінили уявлення про можливості продуктивних сил, постала необхідність у задоволенні інформаційних потреб суспільства. Основним якісним наслідком становлення інформаційної економіки щодо управління вважають, по-перше, перехід від реалізації спеціалізованих функцій менеджменту й централізованого управління до децентралізованого управління та індивідуального самоуправління i, по-друге, послаблення основного принципу управ- ління, побудованому на лінійному мисленні (основне завдання якого послаблення або нейтралізація дії несприятливих чинників для цього рівня гомеостазу) i посилення дії сприятливих чинників, які базуються на нелінійній логіці (основне завдання якої - перехід системи від одного рівня гомеостазу до іншого). Інформаційне забезпечення управління передбачає як суто інформацію (сукупність інформаційних одиниць або інформаційних блоків, що характеризують внутрішнє й зовнішне середовище системи), так і методи їх побудови й розрахунку, сукупність характеристик руху інформації, результати оцінки якості інформації та способи переробки інформації (Chornous, 2014).

Основою проактивного управління має стати виробництво когнітивної, систематизованої інформації знань на основі новітніх інформаційних технологій через аналіз інформаційних потоків, які розглядаються як потужний стратегічний ресурс. При цьому аналітичний бізнес-інтелект доповнюється когнітивним бізнесінтелектом, який дозволяє виявити прихований (латентний) зміст інформації значення, ідеї, фактори, тенденції, закономірності, центри сил, загрози, ризики, суперечності, проблеми у хаосі різнопланової інформації. Враховуючи визначені латентні елементи, можна приймати ефективні управлінські рішення, розподіляти сили та кошти, запускати нові позитивні процеси та зупиняти ті, що гальмують (як негативні, так і застарілі, неактуальні), оскільки прискорені зміни зовнішнього середовища та внутрішнього стану систем ставлять принципово нові завдання перед управлінням передбачити зміни та забезпечити випереджальний розвиток. Такі завдання виникають дедалі частіше й можуть потребувати для своєї реалізації не лише оперативних, а й стратегічних, і навіть цілепокладаючих рішень.

I. Ансофф виділяє чотири етапи в розвитку систем (методів) управління (Chornous, 2014):

- Управління на основі контролю за виконанням (постфактум).

- У Упавління на основі екстраполяції, коли темп змін прискорюється, але майбутнє ще можна передбачати шляхом екстраполяції минулого.

- $\quad$ Управління на основі передбачення змін, коли почали виникати несподівані явища, і темп змін прискорився, однак не настільки, щоб не можна було вчасно передбачити майбутні тенденції і сформувати реакцію на них.

- Управління на основі гнучких екстрених рішень, коли багато важливих завдань виникають настільки стрімко, що їх неможливо вчасно передбачити.

- Виклад основного матеріалу. В сучасних умовах, коли надзвичайно зростає значення фактора часу, управління як реагування на вже виниклі ситуації не лише втрачає свою ефективність, а й призводить до збільшення втрат унаслідок вимушеної затримки управлінських дій. Інформаційне суспільство вимагає застосування проактивного типу мислення та відповідних йому методів управління, що засновані на:

- постійному моніторингу, тобто відстеженні параметрів процесів усередині системи і тієї частини зовнішнього середовища, яка впливає на систему;

- $\quad$ постійному аналізі результатів моніторингу та 
інформуванні керівництва про результати аналізу;

- $\quad$ класифікації реакцій на поточний стан системи, що потребує або оптимізації оперативних управлінських впливів, або формування оптимальних стратегічних рішень, або навіть рішення про необхідність зміни чи оптимізації цілей.

Управління як історичний процес бере початок 3 моменту усвідомлення людиною необхідності регулювати спільну діяльність колективів. Як відомо, управління як науку визнали в 1911 році після опублікування Ф. Тейлором дослідження «Принципи наукового менеджменту». 3 того часу наука про управління розвивається не як низка послідовних, взаємопов'язаних розділів теорії, а як окремий напрям досліджень 3 теорії та практики управління. Так, Р.Фатхутдінов пропонує розширену класифікацію підходів до теорії і практики управління, куди включає цілий ряд підходів. Разом 3 тим можна зробити висновок, що відокремлене практичне використання багатьох альтернативних підходів $\epsilon$ недоцільним: вони $є$ інтегрованими в усталені основні підходи до управління і прийняття управлінських рішень. М. Мескон, М. Альберт, Ф.Хедоурі виділяють чотири найважливіші підходи, які зробили істотний внесок у розвиток теорії і практики управління, підхід 3 позицій виділення різних шкіл, процесний підхід, ситуаційний та системний підходи (Chornous, 2014).

За підходу з позицій виділення різних шкіл в управлінні менеджмент розглядається з різних точок зору. Особливу увагу заслуговує, на наш погляд, так звана «нова школа наукового менеджменту», яка грунтується на впровадженні методів та інструментів природничих наук у дослідженні управлінської діяльності. Представники цієї школи займаються дослідженням процесів прийняття рішень, що можуть бути підтримані новітніми математичними методами та сучасними інформаційними технологіями. Кількісний підхід до управління, який розвивається в науковому менеджменті завдячуючи розвитку точних наук і обчислювальної техніки, дозволяє не просто скорочувати час на розв'язання складних управлінських завдань, а й поглиблювати розуміння складних управлінських проблем завдяки розробці і реалізації моделей, підвищуючи при цьому раціональність рішень. Математичний інструментарій підтримки прийняття рішень продовжує удосконалюватись, поєднуючи різні підходи. Цю тенденцію ілюструє сьогодні потужний інструментарій, що надає, наприклад, інтелектуальний аналіз даних, який поєднує в собі досягнення штучного інтелекту, чисельних математичних методів, статистики, евристичних підходів.

Рефлексивне управління вимагає отримання інформації про супротивника або про партнера в будь-який спосіб. Механізми рефлексивного управління розглядають взаємодію протилежностей або антагоністів i вивчають процес передачі одним супротивником іншому підстав для прийняття рішень. У рефлексивному виборі суб'єкт, оцінивши ситуацію, впливає на формування своєї поведінки та можливості вибору. Рефлексивне управління це вплив на супротивника або партнера 3 метою прийняття ним вигідного для нас рішення. Рефлексивні процеси найбільш рельєфно проявляються не тільки у конфліктних ситуаціях і суперництві, а й у процесі співробітництва і партнерства. Рефлекси- вне управління передбачає пізнання ситуації і прийняття рішення для впливу на неї на основі іiі модельного подання. Взаємозв'язок між мисленням суб'єкта і ситуацією, в якій він бере участь, представляється двома функціональними залежностями: пізнання ситуації як когнітивна функція, а вплив умовиводів на ситуацію в реальному світі впливовою або активною функцією. У когнітивній функції сприйняття учасником ситуації залежать від ситуації; у впливовій функції сприйняття учасників впливають на ситуацію. Таким чином, управління являє собою постійне розв'язання потоку проблем, які породжують зовнішнє й внутрішнє середовище, що динамічно змінюються, а також результат ітерації когнітивної і впливової функції. Рефлексивне управління $є$ одним з видів інформаційних впливів, які вивчає інформаційне управління.

Виникнення інформаційного суспільства створило ще один вектор стану зовнішнього середовища інформаційний, який впливає на керівників і, керуючи яким вони, у свою чергу, можуть впливати на конкурентів i партнерів, Так з'явився новий метод управління інформаційне управління, що передбачає управління інформацією, яку мають учасники на момент прийняття рішення.

Під інформаційним управлінням розуміється процес вироблення та реалізації управлінських рішень в ситуації, коли керуючий вплив має неявний, непрямий характер, а об'єкту управління надається визначена суб'єктом управління інформація про ситуацію (інформаційна картина), орієнтуючись на яку цей об'єкт нібито самостійно обирає лінію своєї поведінки. Інформаційне управління виходить із розуміння того, що найбільшу складність відображення реальності визначає інформаційне поле, створюване засобами інформації. Людина формується у взаємозв'язку з іншими людьми в соціумі і «управляється» лише інформацією. В різних сферах соціальної взаємодії використовуються різні методи прихованого для людини впливу, примусу до необхідної поведінки та дій.

Оскільки управління передбачає вплив на керовану систему з метою забезпечення необхідної поведінки, то управління такою системою полягає в спонуканні людей до необхідної поведінки. Суттєвою при цьому $є$ інформованість суб'єкта інформація, яку він має на момент прийняття рішення про допустимі альтернативи, їхні переваги, наслідки вибору тієї чи іншої альтернативи тощо. Структура інформованості суб'єкта включає в себе його уявлення про стан природи та про уявлення опонентів, повідомлення про які можуть бути елементами інформаційного впливу. Серед видів інформаційних впливів виділяють інформаційне регулювання, рефлексивне управління та активний прогноз. При цьому інформація може включати як «сухі» дані та факти, так і логічно обгрунтовані висновки, аналітичні судження, що спираються на певний набір фактів i повідомляють про майбутні значення певних параметрів, що залежать від стану природи і дій агентів. Під інформаційним управлінням розуміється процес вироблення та реалізації управлінських рішень в ситуації, коли керуючий вплив має неявний, непрямий характер, а об'єкту управління надається визначена суб'єктом управління інформація про ситуацію (інформаційна 
картина), орієнтуючись на яку цей об'єкт нібито самостійно обирає лінію своєї поведінки.

Механізм інформаційного впливу заснований на маніпуляції свідомістю через внесення до неї цілеспрямованої достовірної або недостовірної інформації.

Цей тип управління людиною або організацією пов'язаний $з$ прагненням так сформувати повідомлення про реальну ситуацію, щоб, незважаючи на його неадекватність, об'єкт управління приймав його як об'єктивне і діяв відповідним чином. Тобто кінцевою метою інформаційного впливу $є$ бажана поведінка об'єкта управління, що постулюється суб'єктом.

Ефективність інформаційного управління значною мірою залежить від розуміння психології об'єктів впливу, якими можуть розглядатися як особистість, так і організація, і масове суспільство.

Будь-який інформаційний вплив планується 3 метою зміни внутрішніх мотивів та переорієнтації поведінки об'єкта в необхідному напрямку.

Основною особливістю прийняття та реалізації інформаційних управлінських рішень $є$ те, що це не одноразовий акт, а сукупність взаємопов'язаних дій i методів їх реалізації, розподілених на деякому часовому інтервалі, за територією і за сегментами цільової аудиторії. Більшість цих етапів реалізується в рамках медіа планування (Chornous, 2014).

Процес інформаційного управління має починатися 3 ретельного вивчення стану та передісторії процесів розвитку об'єкта управління як системи з метою виявити в ньому якісні, ключові зміни, оцінити можливості сегментації і дати якісну оцінку основних параметрів виділених сегментів. Це дозволить розділити всі фактори поведінки системи на основні та другорядні і формалізувати вміст системи.

Концепція інформаційного управління повинна містити стислу характеристику сфери, в якій здійснюється планування розвитку, короткий опис стану і найважливіших факторів, що впливають на цю систему і ситуацію, в тому числі прогноз основних подій на прогнозований період, перелік завдань, перелік і загальний опис методів і засобів управління, які слід використовувати для реалізації стратегії і тактики.

Осмислення і освоєння цінності рефлексивного та інформаційного підходів до управління вимагає спільних зусиль учених різних наукових напрямів. Аналітичний огляд основних підходів до управління і прийняття управлінських рішень дозволяє стверджувати, що до сьогодні не сформувалося єдиної загальновизнаної теорії управління, навпаки, спостерігається підсилення диференціації досліджень у галузі проблем управління. Разом $з$ тим чітко простежується тенденція взаємної інтеграції різних шкіл і напрямів на базі певних єдиних концепцій. Таким плідним поєднанням виступає залучення проактивного підходу до ситуаційного управління, що приводить до формування концептуальних основ проактивного управління.

Концепція впровадження інформаційних технологій в систему менеджменту почала реалізовуватись в Україні в середині $60-\mathrm{x}$ років XX століття шляхом створення так званих автоматизованих систем управління (АСУ). Під керівництвом директора інституту кібернетики АН України академіка Глушкова В.М. були сфо- рмульовані основні принципи розробки, що знайшло своє відображення при побудові різних типів АСУ. Починаючи з кінця 60-х років XX ст. і дотепер відбувається запровадження інформаційних технологій в систему управління підприємством: об'ємнокалендарне планування (Master Planning Schedule MPS), планування необхідних матеріалів (Material Resource Planning MRP), планування виробничих ресурсів (Manufacturing Resource Planning MRP II), планування необхідних потужностей (Capacity Requirements Planning CRP), планування фінансових ресурсів (Finance Requirements Planning FRP), управління ресурсами підприємства (Enterprise Resource Planning ERP), управління взаємовідносинами з клієнтами (Customer Relationship Management CRM), управління ланцюгом поставок (Supply Chain Management SCM), планування ресурсів, синхронізоване з покупцем (Customer Synchronized Resource Planning CSRP), управління ресурсами та зовнішніми відносинами підприємства (Enterprise Resource and Relationship Planning ERP II), управління загальною ефективністю підприємства (Common Performance Management СРM), системи документообігу (Enterprise Content Management ECM) тощо.

Споживачами систем ERP, як правило, є промислові компанії, які мають намір значно скоротити витрати на забезпечення ефективного функціонування всіх підрозділів компанії. Системи SCM в основному використовують ТНК для забезпечення високого рівня взаємодії з усіма ланками ланцюга постачань і з кінцевими споживачами, враховуючи зростання ролі електронної торгівлі.

\section{Висновки}

Управління, як наука, за свою майже столітню історію інтенсивно розвивається, що відображається у відповідних підходах та наукових школах. Еволюція інформаційних технологій відкрила новий етап розвитку системи менеджменту завдяки появі глобального інформаційного простору. Становлення та розвиток інформаційного суспільства, його послідовний перехід до суспільства знань, зростання ролі та місця інформаційно-комунікаційних технологій в цих процеcax, поспряли тому, що саме розроблення концептуальних засад ефективного проактивного механізму підготовки й прийняття управлінських рішень, наукових теоретичних та методичних положень зі створення та впровадження в практику такого механізму, формалізація його до рівня конкретних економікоматематичних моделей та інформаційних технологій повинні стати важливими об'єктами дослідження вітчизняної науки.

\section{Бібліографічні посилання}

Chornous, G.O. (2014). Proaktyvne upravlinnja social'noekonomichnymy systemamy na osnovi intelektual'nogo analizu danyh: metodologija i modeli. K. VPC «Kyi'vs'kyj universytet» (in Ukrainian).

Стаття надійшла до редакиії 26.09.2016 